\title{
Analisis Kualitas Pelayanan Asrama bagi Peserta Didik SMA Negeri 3 Kayuagung Provinsi Sumatera Selatan
}

\author{
Herlina \\ SMAN 3 Kayuagung, Kabupaten Ogan Komering Ilir - Provinsi Sumatera Selatan \\ Corresponding Author. Email: Herlinaiin357@gmail.com
}

\begin{abstract}
This study aims to: 1) analyze the quality of service to students who live in the dormitory of SMAN 3 Kayuagung, and 2) describe the supporting factors and barriers to service for students. This research method uses descriptive quantitative method. The sample of this study amounted to 234 students of class X, XI, and XII. Data collection techniques were carried out through questionnaires, interviews, and observations. While the data analysis technique of this research uses the Importance-Performance Analysis (IPA) method. The results of this study found that six indicators whose performance should be improved by the guardian of the SMAN 3 Kayuagung dormitory, including the condition of a satisfactory and comfortable bedroom, the guardian of the dormitory is given rewards to students who have good jobs, students who lose their belongings must be assisted immediately. The kitchen must prepare the dish on time, the students get security guarantees, and good relationships are established by providing services in the dormitory for students. The dormitory guardian can create a home situation for students to face what they have. To provide criminal sanctions for perpetrators, teachers must involve themselves as parenting teachers by helping the guardian of the dormitory.
\end{abstract}

Abstrak: Penelitian ini bertujuan untuk: 1) menganalisis kualitas pelayanan pada peserta didik yang tinggal di asrama SMAN 3 Kayuagung, dan 2) mendeskripsikan faktor pendukung dan hambatan pelayanannya terhadap peserta didik. Metode penelitian ini menggunakan metode deskriptif kuantitatif. Sampel penelitian ini berjumlah 234 siswa kelas X, XI, dan XII. Teknik pengumpulan data dilakukan melalui kuesioner, wawancara, dan observasi. Sedangkan teknik analisis data penelitian ini menggunakan metode ImportancePerformance Analysis (IPA). Hasil penelitian ini menemukan bahwa enam indikator yang kinerjanya harus ditingkatkan oleh wali asrama SMAN 3 Kayuagung, antara lain kondisi kamar tidur yang memuaskan dan nyaman, wali asrama diberikan reward kepada siswa yang memiliki pekerjaan bagus, siswa yang kehilangan barang harus segera dibantu. Dapur harus menyiapkan hidangan itu tepat waktu, para siswa mendapatkan jaminan keamanan, dan dijalin dengan baik kekerabatan dengan memberikan layanan di asrama untuk siswa. Wali asrama dapat menciptakan situasi rumah agar siswa menghadapi apa yang dimilikinya. Untuk memberikan sanksi pidana bagi pelaku, guru harus melibatkan diri menjadi parenting teacher dengan membantu wali asrama.

\author{
Article History \\ Received: 17-03-2021 \\ Revised: 09-04-2021 \\ Accepted: 22-06-2021 \\ Published: 07-07-2021
}

\section{Key Words:}

Quality, Educational

Services, Dormitories.

High School.

\author{
Sejarah Artikel \\ Diterima: 17-03-2021 \\ Direvisi: 09-04-2021 \\ Disetujui: 22-06-2021 \\ Diterbitkan: 07-07-2021
}

\section{Kata Kunci:}

Kualitas, Pelayanan

Pendidikan, Asrama,

SMA.

How to Cite: Herlina, H. (2021). Analisis Kualitas Pelayanan Asrama bagi Peserta Didik SMA Negeri 3 Kayuagung Provinsi Sumatera Selatan. Jurnal Paedagogy, $8(3), \quad 311-321$. doi:https://doi.org/10.33394/jp.v8i3.3577

d.

https://doi.org/10.33394/jp.v8i3.3577

This is an open-access article under the CC-BY-SA License.

\section{Pendahuluan}

Ada tiga unsur penting dalam pelayanan publik yaitu pertama unsur organisasi pemberi (penyelenggara pelayanan) yaitu pemerintah/ pemerintah daerah, kedua unsur penerima layanan (pelanggan) yaitu orang atau masyarakat atau organisasi yang berkepentingan, ketiga unsur kepuasan yang diberikan dan/atau diterima oleh penerima 
layanan. Pemerintah sebagai service provider (Penyedia Jasa) bagi masyarakat dituntut untuk memberikan pelayanan yang baik atau terbaik.

Sekolah adalah salah satu institusi penyelenggara negara. Berarti sekolah juga berkewajiban untuk kegiatan pelayanan publik. Sebagai lembaga penyedia jasa pendidikan, sekolah perlu inisiatif dan cara untuk meningkatkan kepuasan pelanggan, dalam hal ini adalah peserta didik. dan orangtua peserta didik. Sudah saatnya sekolah sebagai lembaga penyelenggara negara memperhatikan kualitas layanan. Karena kualitas layanan dapat dijadikan tolok ukur untuk mencapai keunggulan kompetitif, dan kualitas layanan merupakan salah satu faktor yang menentukan pemilihan sesuatu yang dapat memuaskan peserta didik. Kepuasan peserta didik akan tercapai apabila kualitas layanan jasa yang diberikan sesuai kebutuhannya.

Sekolah Menengah Atas Negeri (SMAN) 3 Kayuagung merupakan salah satu dari sepuluh sekolah unggul yang ada di Provinsi Sumatera Selatan. Pendirian sekolah ini berdasarkan Surat Keputusan Kepala Kantor Wilayah Depdiknas Provinsi Sumatera Selatan nomor 129/I11/KP/2000 tanggal 24 Januari 2000 tentang Pembukaan SMU-SMU "Unggul" di Sepuluh Kabupaten/Kota dan Surat Keputusan Gubernur Sumatera Selatan nomor: 244/SK/VII/2000 tanggal 30 Mei 2000 tentang Persetujuan Pembukaan SMU-SMU "Unggul” di Sepuluh Kabupaten/Kota Provinsi Sumatera Selatan. Sebagai sekolah unggul SMAN3 Kayuagung memiliki fasilitas asrama.

SMAN 3 Kayuagung selalu menjadi perhatian utama para lulusan Sekolah Menengah Pertama dan Madrasyah Tsnawiyah baik peserta didik dari dalam Kabupaten Ogan Komering Ilir (OKI) sendiri maupun luar Kabupaten OKI. Jumlah pelamarnya pun setiap tahun terus meningkat. Ternyata yang menarik minat para peserta didik dan para orang tua peserta didik terhadap sekolah tersebut bukan semata karena sekolah tersebut adalah sekolah unggulan namun yang lebih mendasar adalah karena sekolah tersebut berasrama dan menerapkan full boarding school. Setiap tahun peserta didik yang melamar ke sekolah ini sangat banyak, tetapi hanya separuhnya saja yang dapat diterima, hal ini disebabkan karena daya tampung asrama yang terbatas jumlahnya. Penelitian ini dilakukan dengan tujuan untuk menganalisis dan mendeskripsikan kualitas pelayanan terhadap peserta didik yang tinggal di asrama SMAN 3 Kayuagung dan mendeskripsikan faktor-faktor yang mendukung dan menghambat pelayanan terhadap peserta didik yang tinggal di asrama SMAN 3 Kayuagung.

\section{Metode Penelitian}

Metode penelitian ini menggunakan metode deskriptif kuantitatif yaitu penelitian yang mengukur kekuatan hubungan antar dua variabel atau lebih untuk menggambarkan sifatsifat (karakteristik) dari objek penelitian yang dilakukan melalui pengumpulan dan analisis data. Pada penelitian ini, kelompok responden adalah peserta didik kelas X, kelas XI, dan kelas XII baik putra maupun putri berjumlah 561 orang peserta didik yang masih bersekolah di SMA Negeri 3 Kayuagung atau masih menikmati pelayanan asrama. Mengingat penerima layanan asrama adalah peserta didik yang berjumlah 561 orang mulai dari kelas X, kelas XI, kelas XII, baik putra maupun putri maka anggota populasi dianggap tidak homogen maka pengambilan sampel dilakukan dengan metode proportionate straified random sampling. Sedangkan cara menentukan jumlah elemen/anggota sampel dari suatu populasi menggunakan rumus Slovin yaitu sebagai berikut:

$$
n=\frac{N}{1+\left(N x e^{2}\right)}
$$


Keterangan:

$\mathrm{n}=$ jumlah elemen/anggota sampel

$\mathrm{N}=$ jumlah elemen/ anggota populasi

$\mathrm{e}=$ Error level (tingkat kesalahan)

(catatan: umumnya digunakan 1 atau $0,01,5 \%$ atau 0,05 , dan $10 \%$ atau 0,1 )

Apabila jumlah seluruh populasi yang akan diteliti adalah 561 orang, dengan error level (tingkat kesalahan) ditetapkan 5\% maka akan diperoleh sampel sebagai berikut:

$$
n=\frac{561}{1+\left(561 \times 0,05^{2}\right)}
$$

$\mathrm{n}=233,75$ atau dibulatkan 234 orang

Berhubung populasi terdiri dari tiga bagian yaitu peserta didik kelas X berjumlah 193 orang, kelas XI berjumlah 173 orang dan kelas XII berjumlah 195 orang, maka jumlah sampel yang diambil berdasarkan masing-masing kelas adalah ditentukan kembali dengan rumus:

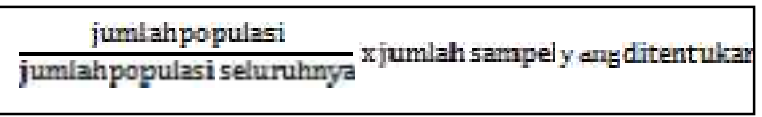

Sehingga dari keseluruhan sampel kelas tersebut adalah 234 sampel,

yaitu : Kelas X: $\frac{193}{b 61} \times 234=80,50$ dibulatkan 81 orang

Kelas XI: $\frac{1 / 3}{b 61} \times 234=12,16$ dibulatkan 72 orang.

Kelas XII: $\frac{175}{b=1} \times 234=81,33$ dibulatkan 81 orang

Teknik pengumpulan data yang digunakan pada penelitian ini yaitu angket yang dibuat berupa pernyataan-pernyataan tertutup. Angket ini diberikan kepada peserta didik, yang dalam hal ini menjadi sampel penelitian. Wawancara adalah suatu teknik pengumpulan data untuk memperoleh informasi sebagai pelengkap dalam penyempurnaan kuisioner. Hal ini dilakukan dengan mewawancarai wali asrama untuk memperoleh informasi tentang faktor-faktor pendukung dan faktor-faktor penghambat pelayanan asrama. Observasi digunakan untuk melakukan kunjungan dan melihat secara langsung keadaan asrama sekolah serta kegiatan yang berlangsung disana. Untuk pengolahan data digunakan bantuan program Microsoft Excell. Sedangkan tingkat kualitas pelayanan yang diberikan diukur dengan Importance-Performance Analysis atau Analisis Tingkat Kepentingan dan Kinerja Kepuasan Pelanggan (Martila and Jhon dalam Supranto 2011). Berdasarkan hasil penilaian tingkat kepentingan dan hasil penilaian kinerja/penampilan maka dihasilkan suatu perhitungan mengenai tingkat kesesuaian antara tingkat kepentingan dan tingkat kinerja.

Dalam penelitian ini terdapat 2 buah variabel yang diwakilkan oleh huruf $\mathrm{X}$ dan $\mathrm{Y}$, dimana: $\mathrm{X}$ merupakan tingkat kinerja pegawai asrama yang dapat memberikan kepuasan kepada peserta didik, sedangkan $\mathrm{Y}$ merupakan tingkat kepentingan peserta didik. Adapun rumus yang digunakan adalah:

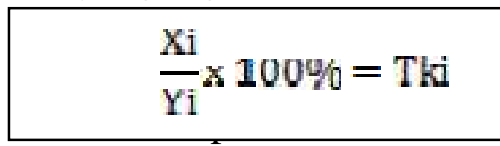

Dimana:Tki = Tingkat kesesuaian responden

$\mathrm{Xi} \quad=$ Skor penilaian kinerja pegawai asrama.

$\mathrm{Yi}=$ Skor penilaian kepentingan peserta didik.

Untuk memudahkan pemahaman, maka pada peneltian ini kata tingkat kinerja disamakan dengan pelayanan dan kata tingkat kepentingan disamakan dengan harapan. 
Selanjutnya dari $\mathrm{X}$ dan $\mathrm{Y}$ dicari rata-rata masing-masing dengan menggunakan rumus:

$$
\overline{\mathrm{X}}=\frac{\sum \mathrm{Xi}_{\mathrm{i}}}{\mathrm{I}} \quad \overline{\mathrm{Y}}=\frac{\sum \mathrm{Yi}_{\mathrm{i}}}{\mathrm{n}}
$$

Keterangan : $\overline{\mathrm{X}}=$ Skor rata - rata tingkat pelaksanaan

\section{$\overline{\mathrm{Y}}=$ Skor rata - rata tingkat kepentingan}

$$
\mathrm{n}=\text { Jumlah responden }
$$

Selanjutnya data diolah kedalam diagram kartesius, dimana sumbu mendatar (X) diisi oleh skor tingkat kinerja (pelayanan), sedangkan sumbu tegak (Y) diisi oleh skor tingkat kepentingan (harapan). Diagram kartesius merupakan suatu bangun yang dibagi atas empat bagian yang dibatasi oleh dua buah garis yang berpotongan tegak lurus pada titik $(\overline{\overline{\mathrm{X}}}, \overline{\mathrm{Y}})$. Dimana $\overline{\bar{X}}$ merupakan rata-rata dari rata-rata skor tingkat kinerja pelaksanaan seluruh faktor atau atribut dan $\overline{\bar{Y}}$ adalah rata-rata dari rata-rata skor tingkat kepentingan seluruh faktor yang mempengaruhi kepuasan peserta didik. Diagram kartesius tersebut dapat dilihat dari gambar berikut:

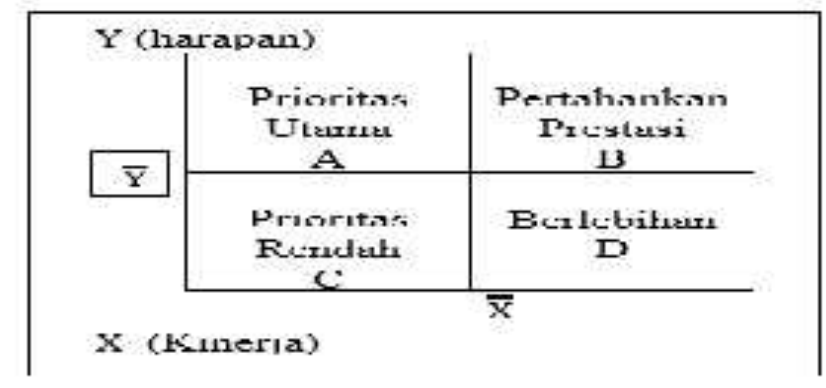

Keterangan:

\section{Gambar 1. Diagram Kartesius}

A. Menunjukkan faktor yang dianggap mempengaruhi kepuasan peserta didik, termasuk unsur-unsur yang dianggap sangat penting, namun pihak asrama belum melaksanakannya sesuai keinginan peserta didik. Sehingga mengecewakan.

B. Menunjukkan unsur jasa pokok yang telah berhasil dilaksanakan pihak asrama, untuk itu wajib dipertahankan. Dianggap sangat penting dan sangat memuaskan.

C. Menunjukkan beberapa faktor yang kurang penting pengaruhnya bagi peserta didik, pelaksanaanya oleh pihak asrama biasa-biasa saja. Dianggap kurang penting dan kurang memuaskan.

D. Menunjukkan faktor yang mempengruhi peserta didik kurang penting, tetapi pelaksanaannya berlebihan. Dianggap kurang penting tetapi sangat memuaskan.

\section{Hasil Penelitian dan Pembahasan}

Penelitian ini berfokus pada pelayanan asrama yang diterima oleh peserta didik di SMAN 3 Kayuagung. Untuk menilai sejauh mana kualitas pelayanan yang diberikan oleh pihak sekolah, perlu adanya kriteria yang menunjukkan apakah suatu pelayanan yang diberikan dapat dikatakan baik atau buruk, berkualitas atau tidak. Persepsi pelanggan terhadap kualitas layanan dapat diukur dan dievaluasi melalui dimensi-dimensi kualitas layanan sebagai berikut: Kualitas servqual mengandung Tangibles; tercermin pada fasilitas fisik, peralatan, personil dan bahan komunikasi; Reliability; kemampuan memenuhi pelayanan yang dijanjikan secara terpercaya, tepat; Responsiveness; kemauan untuk membantu pelanggan dan menyediakan pelayanan yang tepat; Assurance; pengetahuan dari 
para pegawai dan kemampuan mereka untuk menerima kepercayaan dan kerahasian; dan Emphaty; perhatian individual diberikan oleh perusahaan kepada para pelanggan (Zeithaml, 1990 dalam Hardiyansyah, 2011). Kata kualitas mengandung banyak pengertian, menurut Kamus Besar Bahasa Indonesia Edisi Ketiga (2002), kualitas berarti: 1) tingkat baik buruknya sesuatu; 2) derajat atau taraf (kepandaian, kecakapan, dst); atau mutu. Zeithaml et. al. (1990) dalam Tjiptono, (2011) mengatakan bahwa: Service quality (SERVQUAL) is the extent of discrepancy between customer's expectations or desires and their perceptions. Lebih kurang artinya kualitas layanan adalah ketidaksesuaian antara harapan atau keinginan konsumen dengan persepsi konsumen. Tjiptono (2000) mengemukakan bahwa kualitas adalah: (1) kesesuaian dengan persyaratan.; (2) kecocokan untuk pemakaian; (3) perbaikan berkelanjutan; (4) bebas dari kerusakan/cacat; (5) pemenuhan kebutuhan pelanggan sejak awal dan setiap saat; (6) melakukan segala sesuatu secara benar; (7) sesuatu yang bisa membahagiakan pelanggan.

Asrama SMAN 3 Kayuagung terdiri dari 2 (dua) unit bangunan, 1 (satu) unit bangunan Asrama Putra (ASPA) dan satu unit bangunan Asrama Putri (ASPI). Setiap unit bangunan terdiri dari 40 kamar. Ukuran luas masing-masing kamar adalah 6,3 meter x 3,3 meter $=20,79$ meter $^{2}$, padahal ukuran luas kamar asrama standar adalah 36 meter $^{2}$. Setiap kamar rata-rata dihuni oleh 7-8 orang peserta didik. Tiga ruangan teras di asrama putri telah difungsikan pula sebagai ruangan kamar. Masing-masing ukuran teras yang dijadikan kamar tersebut adalah 3,3 meter x 7,5 meter $=24,75$ meter $^{2}$, ketiga kamar tambahan ini dihuni oleh 8 orang peserta didik. Masing-masing Asrama Putra (ASPA) maupun Asrama Putri (ASPI) memiliki kamar mandi 40 unit dan WC 32 unit. Sedangkan penghuni ASPA berjumlah 233 orang dan penghuni ASPI berjumlah 328 orang. Artinya perbandingan untuk kamar mandi putra adalah $1: 6$ sedangkan untuk WC adalah $1: 7$. Untuk putri perbandingan kamar mandinya $1: 8$ dan untuk WC $1: 10$. Sedangkan Ukuran idealnya untuk kamar mandi/WC adalah 1 kamar mandi/WC untuk 5 orang (Tjahyadi: 1997).

Hasil penelitian yang tampak dalam diagram kartesius terlihat bahwa letak unsurunsur pelaksanaan faktor-faktor yang mempengaruhi kepuasan peserta didik terhadap pelayanan asrama SMAN3 Kayuagung terbagi menjadi empat bagian. Adapun penjelasan dari diagram kartesius tersebut adalah:

\section{Kuadran A.}

Kuadran A menunjukkan faktor-faktor yang mempengaruhi kepuasan peserta didik pada kuadran ini penanganannya perlu diprioritaskan oleh pengelola asrama, karena keberadaan faktor-faktor ini yang dinilai penting oleh peserta didik namun pelaksanakannya masih belum memuaskan. Faktor-faktor yang termasuk dalam kuadran ini adalah:

a) Kondisi kamar tidur memadai dan nyaman (8), Menurut pengelola hal ini disebabkan oleh kondisi kamar yang over kapasitas. Kendala yang dihadapi oleh pengelola adalah tidak mungkin menambah jumlah kamar dalam waktu dekat akan tetapi untuk mengurangi jumlah penghuni asrama juga agak sulit, karena besarnya minat masyarakat yang ingin bersekolah.

b) Wali asrama memberikan penghargaan kepada peserta didik yang melakukan perbuatan baik (12). Hal ini merupakan masukan bagi wali asrama sehingga kedepannya akan diperbaiki.

c) Peserta didik yang mengalami kehilangan barang, ditanggapi dengan cepat (13). Untuk hal ini pengelola asrama sudah bekerja sedemikian rupa, setiap kali peserta didik melapor kehilangan selalu ditanggapi. Hanya saja kadang-kadang perlu ditanya dulu apakah betul-betul hilang atau lupa menaruh barangnya. 
d) Petugas dapur selalu menyiapkan makan tepat waktu (17). Menurut keterangan pengelola asrama bahwa petugas dapur sudah menyiapkan makan tepat waktu, hanya saja ada beberapa peserta didik yang melambatkan diri untuk datang ke dapur umum.

e) Peserta didik mendapat jaminan keamanan di dalam asrama (19). Untuk hal ini pengelola asrama hanya mampu mengingatkan peserta didik secara terus menerus untuk menjaga barangnya, mengunci kamar, tidak memperbolehkan membawa HP kamera (mahal), menyiapkan kunci kamar dan memberikan sangsi kepada si pencuri bila kedapatan.

f) Peserta didik mendapat jaminan perlakuan yang menyenangkan penuh kekeluargaan (22). Menurut pengelola asrama, mereka telah memperlakukan peserta didik secara netral, tidak pernah membedakan satu sama lain, hanya mungkin ada peserta didik yang ingin memperoleh perhatian lebih dari pengelola asrama..

\section{Kuadran B}

Kuadran B menunjukkan faktor-faktor yang mempengaruhi kepuasan peserta didik pada kuadran ini perlu dipertahankan karena pada umumnya tingkat pelaksanaannya telah sesuai dengan kepentingan dan harapan peserta didik sehingga memuaskan peserta didik. Faktorfaktor yang termasuk dalam kuadran ini adalah:

a) Kebersihan kamar tidur di asrama (1). Hal ini bisa terjadi karena petugas kebersihan asrama setiap hari datang untuk membersihkan asrama.

b) Kerapian dan kebersihan penampilan wali asrama (5). Yang bertindak sebagai Wali asrama dalam hal ini adalah mereka yang tugas utamanya adalah guru, sehingga penampilan seorang guru juga tetap tercermin dalam tugas mereka sebagai wali asrama.

c) Kerapian dan kebersihan penampilan petugas satpam (7). Petugas satpam sudah memilki kesadaran yang tinggi bahwa mereka adalah petugas yang pertama kali dilihat oleh tamu/masyarakat sehingga mereka harus menjaga penampilan.

d) Perlengkapan tidur (kasur, bantal, guling) dalam kondisi layak pakai (9). Perlengkapan tidur (kasur, bantal, guling) untuk setiap peserta didik selalu disiapkan oleh pengelola asrama setiap awal tahun pelajaran. Jadi ketika peserta didik masuk ke asrama mereka selalu mendapat perlengkapan tidur (kasur, bantal, guling) dalam kondisi baru dan ketika mereka tamat atau keluar dari asrama barang-barang tersebut dapat mereka bawa pulang ke rumah.

e) Wali asrama memperlakukan peserta didik secara kekeluargaan (10). Pengelola asrama telah memperlakukan peserta didik dengan berbagai pendekatan misalnya melakukan kegiatan rujak party, memanggil peserta didik dengan nama panggilan kecil mereka.

f) Wali asrama memberikan pembinaan kepada peserta didik yang melakukan pelanggaran (11). Tentang tugas sebagai wali asrama sudah dibuatkan garis-garis besarnya antara lain memberikan pengarahan dan pembinaan secara rutin tentang tata tertib di asrama, sehingga wali asrama tinggal menjalankan tugas tersebut dengan sebaik-baiknya

g) Peserta didik yang mengalami sakit, ditanggapi dengan cepat (14). Untuk masalah peserta didik yang sakit, pengelola asrama sudah memfasilitasi dengan adanya UKS yang dijaga oleh dua orang petugas medis. Akan tetapi kalau kondisi sakitnya peserta didik tersebut darurat pada waktu malam hari, wali asrama dapat langsung membawanya ke rumah sakit dengan mobil dinas. 
h) Peserta didik yang mengalami masalah perundungan (perbuatan menganggu, mengusik terus-menerus, menyusahkan) diproses dengan cepat (15). Terhadap pelaku perundungan pada tahap awal akan diinterogasi dulu oleh wali asrama, lalu setelah melihat besar kecilnya masalah dapat dikoordinasikan dengan guru BP, atau diteruskan kepada wakil kesiswaan atau langsung kepada kepala sekolah.

i) Petugas kebersihan asrama bertugas setiap hari (16). Seperti hal nya wali asrama untuk tugas petugas kebersihan juga sudah dibuatkan garis-garis besarnya sehingga petugas tidak keluar dari tanggung jawabnya.

j) Peserta didik mendapat jaminan memperoleh perlakuan yang adil (21). Pengelola asrama telah memperlakukan peserta didik secara netral, tidak pernah membedakan satu sama lain.

k) Petugas asrama selalu memberikan pelayanan yang ramah dan sopan (26). Tugas wali asrama yang lain adalah membina, menciptakan dan melaksanakan 10K. Tentu saja untuk melakukan tugas tersebut tidak bisa dengan semena-mena melainkan harus dengan kekeluargaan, keramahan dan kesopanan.

\section{Kuadran C}

Menunjukkan bahwa faktor-faktor yang mempengaruhi kepuasan peserta didik yang berada pada kuadran ini dinilai kurang penting bagi peserta didik sedangkan pelayanannya biasa saja. Faktor-faktor yang termasuk dalam kuadran ini adalah:

a) Fasilitas dipan / tempat tidur yang layak (2). Pada beberapa kamar asrama putra tidak memilki dipan, sehingga mereka hanya mengelar kasur di lantai. Akan tetapi hal tersebut bukan sebuah problem. Peserta didik tidak ada yang komplain karena tidak ada dipan. Malah ada yang sengaja mengergaji dipan mereka yang bertingkat menjadi pendek.

b) Lemari pakaian dapat menampung baju dan barang-barang (3). Kondisi kamar yang over kapasitas tidak memungkinkan bagi pengelola asrama untuk menyiapkan satu orang satu lemari pakaian, namun hal tersebut juga bukan hal yang penting bagi peserta didik, mereka masih dapat menampung/menyimpan pakaian atau barang mereka pada sebuah wadah plastik.

c) Kerapian dan kebersihan penampilan petugas dapur (20). Tidak pernah ada yang memperhatikan penampilan petugas dapur yang tidak memakai celemek, atau tidak menguncir rambut saat memasak.

d) Meja belajar tersedia layak (4). Rata-rata hanya ada satu meja dalam setiap kamar. Namun peserta didik bisa enjoy menggelar tikar di tengah kamar dan belajar sambil tiduran.

e) Peserta didik mendapat jaminan kamar yang bersih (6). Tanggung jawab terhadap kebersihan kamar merupakan tanggung jawab semua penghuninya. Sehingga terkadang mereka melalaikan hal tersebut bila tidak dalam pengawasan dari pengelola asrama.

f) Peserta didik mendapat jaminan menu makan yang memenuhi pedoman gizi seimbang (18). Menu makan pagi umumnya didominasi oleh karbohidrat. Namun hal tersebut bukan hal yang harus dipermasalahkan oleh peserta didik.

g) Wali asrama memberikan perhatian kepada peserta didik jika peserta didik merasa rindu kepada keluarga (23). Peraturan asrama yang memperkenankan peserta didik untuk dapat bermalam di rumah setiap hari sabtu dan kembali lagi ke asrama pada hari minggu sore, sudah cukup mengobati rindu mereka kepada keluarga, namun bagi 
peserta didik yang rumahnya jauh dapat pulang sebulan sekali atau pada saat libur sekolah.

h) Petugas dapur cepat tanggap ketika makanan habis (27). Peserta didik akan menunggu dengan sabar apabila makanan mereka habis.

\section{Kuadran D}

Menunjukkan faktor yang mempengaruhi kepuasan peserta didik dinilai berlebihan, sebab dianggap tidak terlalu penting tetapi pelaksanaannya dilakukan dengan baik sekali oleh pengelola asrama. Faktor-faktor yang termasuk dalam kuadran ini adalah:

a) Wali asrama memberikan perhatian khusus pada peserta didik yang mengalami masalah pribadi (24). Wali asrama memberikan kesempatan kepada peserta didik untuk curhat. Namun tidak banyak peserta didik yang memanfaatkan hal tersebut.

b) Wali asrama meluangkan waktu untuk mendengarkan keluhan peserta didik (25). Wali asrama mempersilakan peserta didik datang ke rumah untuk mendengar keluhan peserta didik, namun tidak banyak peserta didik membagi masalahnya.

Faktor-faktor Pendukung Pelayanan Pada Peserta Didik Yang Tinggal di Asrama SMAN 3 Kayuagung, untuk Dimensi Tangible: memiliki gedung asrama yang permanen, penanaman Pola Hidup Bersih dan Sehat, memiliki tenaga kebersihan yang mencukupi jumlahnya, dukungan orangtua peserta didik dalam pembiayaan. Untuk Dimensi Reliability: petugas yang kompeten, penanaman rasa kekeluargaan diantara peserta didik, antara pengelola asrama dan peserta didik. Untuk Dimensi Responsiveness: Pengorganisasian petugas yang terstruktur dengan jelas. Untuk Dimensi Assurance: kesadaran pribadi peserta didik untuk menjaga barang pribadi, penyediaan kunci kamar secara berkala oleh pengelola asrama. Untuk Dimensi Emphaty: Wali asrama yang mampu mengayomi.

Faktor-faktor penghambat pelayanan asrama; Untuk Dimensi Tangible: Jumlah kamar asrama yang terbatas. Untuk Dimensi Reliability: peserta didik sering tidak jujur terhadap hal yang mereka hadapi, pengelola asrama memiliki tugas lain sehingga tidak bisa fokus. Untuk Dimensi Responsiveness: tenaga kebersihan yang kurang kompeten. Untuk Dimensi Assurance: Kelalaian dalam mengunci kamar, sanksi yang kurang memberatkan, keterlambatan biaya swadana Untuk Dimensi Emphaty: Jumlah peserta didik yang tidak sebanding dengan sehingga sulit memahami satu persatu, kesibukan yang tinggi sehingga tidak ada waktu bersama.

Berdasarkan dimensi yang disampaikan di atas, dapat dianalisis pada setiap indikatornya sebagai berikut:

Tangible; Berdasarkan dimensi tampilan fisik (tangible) menunjukkan bahwa tingkat harapan peserta didik terhadap fasilitas-fasilitas fisik yang diberikan oleh pengelola asrama sangat besar yaitu pada kategori sangat puas, namun pelayanan yang diberikan oleh pengelola asrama baru pada kategori puas. Fasilitas seperti meja belajar, lemari pakaian, yang tidak disediakan oleh pengelola asrama secara optimal, ada beberapa kamar yang tidak memiliki dipan. Untuk fasilitas kamar mandi dan toilet masih kurang karena memang perbandingan tidak sebanding terutama kamar mandi putri sehingga mereka harus antrian yang berakibat pada keterlambatan untuk mengikuti apel pagi. Fasilitas meja belajar yang tidak mencukupi jumlahnya membuat peserta didik harus belajar tanpa menggunakan meja. Padahal menurut Zeithaml penilaian yang menggunakan indra penglihatan (kasat mata) akan memberikan kekuatan yang besar dalam mempengaruhi persepsi para pelanggannya bahwa mereka mempunyai kualitas pelayanan yang baik. Hal ini kiranya dapat menjadi perhatian pengelola asrama. Dan menurut Tjahyadi (1997) beberapa fasilitas yang harus dimiliki asrama sekolah 
yaitu: 1) Memiliki kamar tidur yang cukup luas, 2) Memiliki kamar pakaian yang dilengkapi dengan lemari pakaian serta rak sepatu/sandal, 3) Memiliki kamar makan yang lengkap dengan meja dan kursi, 4) Memiliki kamar mandi dan WC yang memadai dengan jumlah pemakai (kira-kira $1: 5$ dari jumlah penghuni), 5) Memiliki kamar belajar yang cukup luas.

Reliability; untuk dimensi keterpercayaan (reliability), tingkat harapan peserta didik terhadap pengelola asrama berada kategori sangat puas terutama pada faktor penghargaan kepada peserta didik yang melakukan perbuatan baik dan kondisi kamar tidur memadai dan nyaman, ternyata dalam pelayanannya faktor ini belum memuaskan, padahal fungsi kehidupan asrama harus dapat menjadi laboratorium sosiologis, dimana hubungan manusia merupakan kunci utama. Untuk faktor perlengkapan tidur, memperlakukan peserta didik secara kekeluargaan, dan pembinaan kepada peserta didik yang melakukan pelanggaran sudah sesuai harapan peserta didik. Dalam persepsinya dimensi ini adalah paling penting bagi pelanggan dari berbagai industri jasa. Yang dapat dilakukan oleh pengelola asrama adalah kemampuan memberikan pelayanan seperti yang dijanjikan pelayanan yang akurat atau tidak ada error. Hal ini dapat diperoleh melalui pemberian pelatihan secara terus-menerus dan menekankan kerja teamwork.

Responsiveness; Harapan peserta didik untuk dimensi (daya tanggap) (responsiveness) berada pada kategori sangat puas, namun pelayanan pada faktor peserta didik yang mengalami kehilangan barang dan petugas dapur yang menyiapkan makan tepat waktu belum memuaskan. Padahal prinsip dalam mengelola asrama sekolah dikatakan bahwa asrama hendaknya memberikan pengaruh positif dalam pembentukan dan penanaman sikap serta kebiasaan-kebiasaan yang baik pada diri peserta didik, asrama perlu menetapkan tata tertib dan disiplin yang disertai dengan usaha pengawasan untuk membantu pertumbuhan sikap yang baik bagi para penghuni. Yang sudah memenuhi harapan peserta didik adalah tanggapan terhadap peserta didik yang sakit, yang mengalami masalah perundungan, dan kebersihan asrama oleh petugas kebersihan. Pelayanan yang responsif atau yang tanggap sangat dipengaruhi oleh sikap front-line staf. Harapan pelanggan terhadap kecepatan pelayanan akan selalu berubah yaitu mengalami kecenderungan naik dari waktu ke waktu, sehingga harus selalu menjadi perhatian pengelola asrama.

Assurance; Untuk jaminan keamanan di dalam asrama dan perlakuan yang menyenangkan penuh kekeluargaan, pelayanan yang diberikan oleh pengelola asrama belum memuaskan peserta didik. Pengelola tidak boleh mengabaikan hal ini karena fungsi dari asrama adalah harus dapat menciptakan suasana asrama home artinya kultur kehidupan di asrama harus mampu memberikan lingkungan yang penuh kasih sayang.

Sedangkan untuk jaminan kamar yang bersih dan jaminan menu makan yang memenuhi pedoman gizi seimbang pelayanannya tidak menjadi perhatian peserta didik. Walalupun demikian pengelola asrama tetap harus memperhatikan hal tersebut karena secara khusus tujuan penyelenggaraan asrama antara lain; a) memberikan bimbingan kepada peserta didik (penghuni asrama sekolah) dan menanamkan rasa disiplin pada diri peserta didik.

Empathy; Harapan peserta didik terhadap faktor petugas yang selalu memberikan pelayanan yang ramah dan sopan belum memuaskan. Hal ini mungkin dapat dimaklumi bahwa keramahan adalah bagian dari talenta. Ada sebagian orang yang memang mempunyai pembawaan yang ramah dan ada yang tidak. Untuk pelayanan memberikan perhatian kepada peserta didik jika peserta didik merasa rindu kepada keluarga dan cepat tanggap ketika makanan habis memberikan perhatian khusus pada peserta didik yang mengalami masalah pribadi, meluangkan waktu untuk mendengarkan keluhan peserta didik sangat memuaskan. 


\section{Kesimpulan}

Berdasarkan hasil penelitian dapat disimpulkan bahwa; Kualitas pelayanan yang harus ditingkatkan yaitu: pada dimensi reliability adalah kondisi kamar tidur memadai dan nyaman, wali asrama memberikan penghargaan kepada peserta didik yang melakukan perbuatan baik, pada dimensi responsiveness adalah peserta didik yang mengalami kehilangan barang ditanggapi dengan cepat, petugas dapur selalu menyiapkan makan tepat waktu, pada dimensi assurance adalah peserta didik mendapat jaminan keamanan di dalam asrama, peserta didik mendapat jaminan perlakuan yang menyenangkan penuh kekeluargaan.

Faktor pendukung dalam pemberian pelayanan asrama terdapat pada dimensi tangible yaitu tersedianya fasilitas yang memadai dan pada dimensi assurance adalah petugas yang kompeten yang mau dan mampu mengayomi. Sedangkan faktor-faktor penghambat pelayanan asrama terdapat pada dimensi responsiveness adalah jumlah peserta didik yang tidak sebanding dengan para pengelola asrama disamping itu tugas utama mereka sebagai guru juga sudah cukup berat.

\section{Saran}

Berdasarkan hasil analisa dalam penelitian pelayanan asrama SMAN 3 Kayuagung, saran yang diberikan adalah sebagai berikut: Dalam pemberian pelayanan asrama terhadap peserta didik disarankan untuk pengelola asrama, pada dimensi empathy dapat lebih menciptakan suasana home sehingga peserta didik dapat lebih terbuka terhadap hal yang mereka hadapi, pada dimensi assurance memberikan sangsi berat terhadap pelaku kejahatan/kriminal, pada dimensi responsiveness dapat melibatkan semua guru untuk menjadi guru asuh (Parenting Teacher) dalam membantu meringankan beban wali asrama.

\section{Daftar Pustaka}

Arikunto, Suharsimi. (2006). Prosedur Penelitian suatu Pendekatan Praktek, Jakarta: PT. Rineka Cipta

Hardiyansyah. (2011). Kualitas Pelayanan Publik, Konsep, Dimensi, Indikator dan Implementasiny. Yogyakarta: Gava Media. (2015). Komunikasi Pelayanan Publik, Konsep dan Aplikasi. Gava Media: Yogyakarta

Lukman, Sampara. (2000). Manajemen Kualitas Pelayanan. Jakarta: STIA-LAN Press

Noor, Juliansyah. (2015). Metodologi Penelitian, Skripsi, Tesis, Disertasi, dan Karya Ilmiah. Jakarta: Prenadamedia Group

Pengertian Asrama Sekolah (Boarding School) Manajemen Layanan Khusus. diakses 27 April 2016 website:https://manajemenlayanankhusus.wordpress.com/

Prayitno, Duwi. (2016). SPSS Handbook, Analisis Data, Olah Data, \& Penyelesaian Kasuskasus Statistik. Yogyakarta: MediaKom

Pedoman Perencanaan Gedung Sekolah Menengah Umum. (1987). Jakarta: Departeman Pekerjaan Umum

Poerwadarminta, WJS. (2011). Kamus Umum Bahasa Indonesia Edisi Ketiga. Jakarta: Balai Pustaka

Pusat Bahasa Departemen Pendidikan Nasional. (2002). Kamus Besar Bahasa Indonesia Edisi Ketiga. Jakarta: Balai Pustaka

Sugiyono. (2008). Metode Penelitian Administrasi. Bandung: AlfaBeta

Sugiyono. (2016). Metode Penelitian Pendidkan (Pendekatan Kuantitatif, Kualitatif dan $R \& D$., Bandung: Alfabeta

Supranto. (2011). Pengukuran Tingkat Kepuasan Pelanggan. Jakarta: Rineka Cipta 
Tjahyadi, Sunarto. (1997). Data Arsitek. Jakarta: Erlangga

Tjiptono, Fandy. (2000). Manajemen Jasa. Yogyakarta: Andi Offset

Tjiptono, Fandy. (2004). Prinsip-Prinsip Total Quality Service. Yogyakarta: Andi Offset

Tjiptono, Fandy; Chandra Gregorius. (2011). Service, Quality \& Satisfaction edisi 3. Yogyakarta: Andi

Undang-undang Republik Indonesia Nomor 20 Tahun 2003 Tentang Sistem Pendidikan Nasional. 2003. Jakarta: Departemen Pendidikan Nasional Republik Indonesia 